\title{
Antonymy in the Legal Terminology: Diachronic Analysis
}

\author{
Dr. Svjetllana Titini
}

University “Aleksander Moisiu”, Durres, Albania; svjetllana.titini@yahoo.com

\section{Doi:10.5901/ajis.2015.v4n3s1p237}

\section{Introduction}

Antonymy is a phenomenon that comes from the relation between the words with opposite meaning in the lexical system of the language. The antonymic relations are the base of scientific and practical recognition of the world reflected through the language. These relations reveal the meaning of the antonym pairs by distingushing them from each other in the degree of understanding the newer dinstinctive features. Various scholars state that in terminology there are the same principles of the notion confrontation, the formation of the antonym pairs and the semantic relations between these pairs as in the everyday language.

However, antonymy in terminology has some features that are associated with the number of terminology elements that form antonymic terms, with the possibility of creating antonimic pairs according to the meaning of the word and the relations it creates in the terminology system, or by creating new antonymic links in terminology but different from those that may be created in the area of general language (Pasho, 1986). The systemic character of the antonymic relations notes: a) the relationship of the compound nouns with a common or similar lexical meaning because of logical-material relation that exists between opposite notions. For example the antonymic pairs civil - penal, privat - publik, each are joined with a similar word circle as: e drejtë, përgjegjësi, çështje, kod dhe pronë, e drejtë; b) in different antonymic relations that are created from the same word, when in different menaings there are formed different terminologic compounds. For exapmle the adjective fizik in the compound person fizik creates an antonymic relation with the adjective juridik (person juridik), but in the compound dëm fizik creates a antonymic relation with the adjective moral (dëm moral); the noun lindje in the compound lindje e personit creates an antonymic relation with the noun emrin vdekje (vdekje e personit); but in the compound lindje detyrimi the relation is with the shuarje (shuarje detyrimi); c) the idea that na antonymic pair gives to another pair as a result of the rules that characterise the opposite relations for example the qualities as $i$ pjesëtueshëm, $i$ kërkueshëm (detyrim) relate to the opposite $i$ papjesëtueshëm, $i$ pakërkueshëm. Antonymy is a phenomenon which expresess the systematic character of the terminology development through the systemic relations of the notions.

\section{The Diachronic Analysis}

The phenomenon of antonymy in the legal terminology in Albanian language in this study will be analysed by comparing th the development and the changes that have happened in two time periods: a. From 1945 -1990 and b. From 1990 to today.

1. In the legal terminology from one time period to the other, based on what they name we notice these antonymic pairs:

a. Pairs that name features and qualities:

Before 1990: (provë) direkte - (provë) indirekte, i fajshëm - i pafajshëm, (person) fizik - (person) juridik, (palë) gjyqbjerrëse - (palë) gjyqfituese, i ligjshëm - $i$ kundërligjshëm, (mandat) i pakufizuar - (mandat) $i$ kufizuar, (organ) individual - (organ) kolegjial, (kontratë) konsensuale - (kontratë) reale, (dispozitë) lejuese - (dispozitë) ndaluese, i paditur i kundërpaditur, (i burgosur) i pagjykuar - (i burgosur) i gjykuar, i parashkrueshëm - i paparashkrueshëm; (e drejtë) absolute - (e drejtë) relative, (rezervë) e domosdoshme - (rezervë) fakultative, (organ) gjyqësor - (organ) jogjyqësor, (kontratë) kryesore - (kontratë) aksesore, (send) i gjetur - (send) i humbur, (traktat me karakter) ofensiv - (traktat me karakter) difensiv, (dëm) pasuror - (dëm) jopasuror, (çështje) penale - (çështje) civile, (direktivë) e përgjithshme (direktivë) individuale le veçantë, (banim) i përkohshëm - (banim) i përhershëm, (organizatë) regjionale - (organizatë) universale, (detyrime) solvabël - (detyrime) insolvabël etc.

After the' 90: (ortak) mazhoritar - (ortak) në minorancë, (tatimpagues) rezident - (tatimpagues) jorezident; (servitud) 
aktiv - (servitud) pasiv, (arrestim) arbitrar - (arrestim) i rregullt, kushtetues - jokushtetues, (e drejtë komunitare) origjinale (e drejtë komunitare) e derivuar, (ent) privat - (ent) publik, (organizatë) qeveritare - (organizatë) joqeveritare, (përmbarues) shtetëror - (përmbarues) privat etc.

b) pairs that name phenomenons:

Before the '90: centralizim (i pushtetit) - decentralizim (i pushtetit), emigracion - imigracion, huadhënie - huamarrje, kolonializëm - dekolonializëm, mitëdhënie - mitëmarrje, monogami - poligami /bigami, suzerenitet - vasalitet etc.

After the '90: kriminalizim - dekriminalizim, penalizim - depenalizim etc.

c) pairs that name people according to their actions they perform:

Before the '90: depozitues - depozitëmbajtës, huadhënës - huamarrës, kreditor - debitor, mitëdhënës- mitëmarrës, paditës - kundërpaditës etc.

After the '90: depozitar/depozitmarrës - depozitëdhënës, enfiteozdhënës- enfiteozmarrës, franshizdhënës franshizmarrës etc.

d) pairs that name an action:

Before the '90: dhënie (e dënimit) - heqje (e dënimit), emërim - shkarkim, fitim (i pronësisë) - humbje (e pronësisë), lidhje (e martesës) - zgjidhje (e martesës), lindje (detyrimi) - shuarje (detyrimi), njohje (e atësisë) - çnjohje (e atësisë), pranim (i padisë) - rrëzim (i padisë), shpallje (e gjendjes së jashtëzakonshme) - heqje (e gjendjes së jashtëzakonshme) etc.

A particular group is the one of pairs which are created from the opposition through the terms of action and inaction for example before 1990: dënim (pa ligj) - mosdënim (pa ligj), dhënie (e mjeteve për jetesë) - mosdhënie (e mjeteve për jetesë), ekzekutim - mosekzekutim, fillim (i çështjes penale) - mosfillim (i çështjes penale), kallëzim (i krimit) moskallëzim (i krimit), njoftim (i ndryshimit të vendbanimit) - mosnjoftim (i ndryshimit të vendbanimit), njohje (e ligjit) mosnjohje (e ligjit), parashkrim (i ndjekjes penale) -mosparashkrim (i ndjekjes penale), paraqitje (e dëshmitarit) mosparaqitje (e dëshmitarit), përmbushje (e detyrimeve kontratore) - mospërmbushje (e detyrimeve kontratore), pranim (i kontratës) - mospranim (i kontratës), ulje (e dënimit) - shtim (i dënimit), ushtrim (i së drejtës së ankimit) - mosushtrim (i së drejës së ankimit), veprim (i paligjshëm) - mosveprim (i paligjshëm), vërtetim (kushti) - mosvërtetim (kushti), zbatim (detyrimi) - moszbatim (detyrimi) etc.

After the '90: administrim (i provës në seancë gjyqësore) - mosadministrim (i provës në seancë gjyqësore), denoncim - mosdenoncim, penalizim - mospenalizim, gjykim - mosgjykim etc.

e) pairs that name different right notions:

Before the '90: aftësi (për të vepruar) - paaftësi (për të vepruar), dhunueshmëri (e banesës) - padhunueshmëri (e banesës), fajësi - pafajësi, ligjshmëri - paligjshmëri, masë - kundërmasë, padi - kundërpadi, pajtueshmëri (e ligjeve me kushtetutën) - papajtueshmëri (e ligjeve me kushtetutën), përgjegjësi (penale) - papërgjegjësi (penale), propozim kundërpropozim, shtetësi - pashtetësi, zotësi (për të vepruar) - pazotësi (për të vepruar) etc.

After the '90: ankim - kundërankim, apelueshmëri (e vendimit) - paapelueshmëri (e vendimit), kushtetueshmëri pakushtetueshmëri, ligjshmëri - kundërligjshmëri, pozitë - opozitë, rekurs - kundërrekurs, shpërblim - kundërshpërblim, tjetërsueshmëri (pronës) - patjetërsueshmëri (e pronës), transmetueshmëri (e detyrimit) - patransmetueshmëri (e detyrimit) etc.

2. The antonymic pairs according to the types of the logical relations between them may show:

a) opposition based on the presence or absence of a quality or feature of the item for example (pronë) $e$ luajtshme - (pronë) e paluajtshme, i fajshëm - i pafajshëm, (detyrim) i kërkueshëm - (detyrim) $i$ pakërkueshëm, (ortak) i kufizuar - (ortak) i pakufizuar, ligjshmëri -paligjshmëri, ndëshkueshmëri pandëshkueshmëri, shtetësi- pashtetësi, (organizatë) qeveritare -(organizatë) joqeveritare, (padi) direkte (padi) indirekte etc.

b) opposition based on the degree of the different measurement of the presence of the same quality of the item of phenomenon. For example (sovranitet) absolut - (sovranitet) relativ, (bashki) e madhe - (bashki) e vogël, (gjobë) e rëndë - (gjobë) e lehtë, (dënim) maksimal - (dënim) minimal, (pronë) shërbyese - (pronë) mbizotëruese etc.

c) opposition based on the opposite notions, for example (dekret) emërimi - (dekret) shkarkimi, fitim (i pronësisë) - humbje (e pronësisë), (deklarim) $i$ luftës - (deklarim) $i$ paqes, (rrethana) lehtësuese (rrethana) rënduese, (dëm) material - (dëm) moral, (dëshmi) me të dëgjuar - (dëshmi) me shkrim, (dispozitë) ndaluese - (dispozitë) lejuese, (diskriminim) negativ - (diskriminim) pozitiv, (detyrim) në para (detyrime) në natyrë, (detyrim) penal - (detyrim) civil etc.

3. The antonymic pairs according to the view of the language heritage of the comppounds can be created: 
a) between two foreign terms for example (sovranitet) absolut - (sovranitet) relativ, centralizim (i pushtetit) decentralizim (i pushtetit), (proces) civil - (proces) penal, (invokabilitet) maksimal (direktivash) (invokabilitet) minimal (direktivash), mazhorancë - opozitë, (detyrime) solvabël - (detyrime) insolvabël, suzerenitet - vasalitet etc.

b) Between an Albanian word and a foreign word for example (rezervë) e domosdoshme - (rezervë) fakultative, (normë) juridike - (normë) zakonore, marrëveshje - konflikt etc.

c) Between two Albanian words for example p.sh dhurimmarrës - dhurues, (gjobë) e rëndë - (gjobë) e lehtë, (pronë) e luajtshme - (pronë) e paluajtshme, fajësi - pafajësi, (vendim) $i$ ligjshëm -(vendim) $i$ paligjshëm, (akt) ligjor - (akt) joligjor, (deklarim) me gojë - (deklarim) me shkrim, (gjykatë e shkallës) së fundit - (gjykatë e shkallës) së parë, të drejta (bashkëshortore) - detyrime (bashkëshortore), (gjykim me dyer) të mbyllura - (gjykim me dyer) të hapura, trashëgimtar -trashëgimlënës, (ekzekutim) vullnetar (ekzekutim) i detyrueshëm etc.

4. Based on the lexical and grammar belonging the antonyms are nouns and adjectives and less verbs.

a) inside the group of the antonymic pair nouns according to the meaning we can notice terms that label: i) abstract notions as: apelueshmëri - paapelueshmëri, fajësi - pafajësi, kushtetueshmëri pakushtetueshmëri, ligjshmëri - paligjshmëri, pozitë - opozitë, tjetërsueshmëri - patjetësueshmëri, suzerenitet - vasalitet etc.; ii) actions: veprime: dhënie (e dënimit) - heqje (e dënimit), emërim (i administratorit) - shkarkim (i administratorit, lidhje (e martesës) - zgjidhje (e martesës), lindje - shuarje (detyrimi), pranim (i padisë) - rrëzim (i padisë), ulje (e dënimit) - shtim (i dënimit) etc.; iii) persona: debitor kreditor, depozitues - depozitëmbajtës, dhurimmarrës - dhurues, enfiteozmarrës - enfiteozdhënës, franshizdhënës - franshizmarrës, mitëdhënës - mitëmarrës, paditës - kundërpaditës, trashëgimtar trashëgimlënës etc.

b) Antonymic pairs adjectives according to their meaning may be gathered in qualifying adjectives as: (sovranitet) absolut - (sovranitet) relativ, (servitud) aktiv - (servitud) pasiv, (dënim) maksimal - (dënim) minimal, (diskriminim) negativ - (diskriminim) pozitiv, (bashki) e madhe -(bashki) e vogël, (gjobë) e rëndë (gjobë) e lehtë, (servitud ) i përhershëm - (servitud) i përkohshëm etc.; and relative adjevtices as: (organ) gjyqësor - (organ) jogjyqësor, (detyrim) i kërkueshëm - (detyrim) i pakërkueshëm, (akt) $i$ ligjshëm - (akt) $i$ paligjshëm, (ligj) kushtetues - (ligj) antikushtetues, (dispozitë) lejuese - (dispozitë) ndaluese, (dëm) pasuror - (dëm) jopasuror, (organizatë) qeveritare - (organizatë) joqeveritare, (organizatë) regjionale (organizatë) universale, (pronë) shërbyese - (pronë) mbizotëruese etc.

c) Antonymic pairs verbs are some as: marr me qira - jap me qira, padit - kundërpadit, penalizoj depenalizoj.

d) Antonymy between the terms which belong in the same lexical grammar category, not rarely are the source for the new formation of the more complete or more limited terms. It is the case when through the wordforming means from the terms of the same root there are new terms formed with opposite meanings to the producting terms. For example centralizoj, centralizim, i centralizuar, centralizues - decentralizoj, decentralizim, i decentralizuar, decentralizues; kushtetues, kushtetueshmëri - antikushtetues, antikushtetueshmëri; padi, padit, paditës, i paditur - kundërpadi, kundërpadit, kundërpaditës, $i$ kundërpaditur, penalizoj, penalizim, i penalizuar - depenalizoj, depenalizim, i depenalizuar, mitëdhënie, mitëdhënës - mitëmarrje, mitëmarrës; suzerenitet, suzeren - vasalitet, vasal; i ligjshëm, ligjshshmëri - $i$ paligjshëm, paligjshmëri; fajësi, i fajshëm - pafajësi, i pafajshëm etc.

e) A particular group consists of the antonymic pairs in which the opposition is realized from words that belong to various lexical and grammar categories as: (ortak) mazhoritar -(ortak) në minorancë, (dëshmi) me të dëgjuar - (dëshmi) me shkrim, (shoqëri) e personit -(shoqëri) kolektive etc.

There are some antonymic pairs created from a word and a compond as: (gjykim) me një gjygtar - (gjykim) me trup gjykues, (seancë) publike - (seancë) me dyer të mbyllura etc.

5. From the structural composition we distinguish antonym with different base and antonyms with the same base.

a) The pairs with different base the antonymic meaning is a consequence of the meaning opposition of the terms for example: (sovranitet) absolut - (sovranitet) relativ, (rezervë) e domosdoshme - (rezervë) fakultative, (normë) juridike - (normë) zakonore, (dëm) material -(dëm) moral, mazhorancë - minorancë, (çështje) penale - (çështje) civile, suzeren - vasalitet etc.

b) In the antonymic pairs with the same base, the opposition is the result of meaning the meanings of prefixes used, therefore, antonymy, in these cases is the result of the process of word formation. There 
are two types of oppositions distinguished: the first is carried out by the formation of words with prefixes of opposite meaning: njohje(e atësisë) - çnjohje (e atësisë), kushtetues - jokushtetues, rekurs - kundërrekurs, kallëzim - moskallëzim (i krimit), i sekuestrueshëm - i pasekuestrueshëm, centralizim - decentralizim (i pushtetit), (provë) direkte - indirekte, (detyrime) solvabël - insolvabël etc. and the second is realized by forming words with different prefixes joined to the same word formation base for example mikroshtet makroshtet, i paralindur - i paslindur.

A special place is occupied by pairs in which the antonymic opposition is realized from the opposite meanings of the composite components such as enfiteozmarrës - enfiteozdhënës, franshizdhënës - franshizmarrës, gjyqbjerrës gjyqfitues, mitëdhënie - mitëmarrje etc.

Antonymic pairs which come from the process of word formation, accoring to the number of morpheme bases in the word structure can be: 1) antonymic pairs between simple terms that have only one such morpheme base such as: njohje e (atësisë) - çnjohje (e atësisë), ankim - kundërankim, njohje (e ligjit) - mosnjohje (e ligjit), pajtueshmëri (me ligjin) - papajtueshmëri (me ligjin), ligjshmëri - paligjshmëri etc .; 2) antonymic pairs that consist between the compound terms that have two morpheme bases such as: huadhënie - huamarrje, mitëdhënie - mitëmarrje, miëtdhënës- mitëmarrës, franshizdhënës - franshizmarrës, enfiteozmarrës - enfiteozdhënës etc. and 3) antonymic pairs between simple terms and composite terms such as: depozitues - depozitëmbajtës, depozitar - depozitëdhënës, dhurues - dhurimmarrës, trashëgimtar - trashëgimlënës etc.

6. In the area of the antonymic issues another problem is the degree of the opposition meaning

a) Antonymy is complete when the meaning of the antonymic pairs are totally opposite as: (diskriminim) negativ (diskriminim) pozitiv, (gjobë) e rëndë - (gjobë) e lehtë, (gjykim me dyer) të hapura - (gjykim me dyer) të mbyllura, (servitud) aktiv - (servitud) pasiv, (e drejtë) absolute - (e drejtë) relative etc. and b) in a lower degree when the opposition is not complete as in the case of the fromation with the prefixes such as: jo, mos, pa for example (organ) gjyqësor (organ) jogjyqësor, (vendim) përfundimtar - (vendim) jopërfundimtar, (ortak) statutor - (ortak) jostatutor, pasuri - jopasuri, zbatim (i një urdhërshërbimi) - moszbatim (i një urdhërshërbimi), dënim - mosdënim, (mocion) besimi - (mocion) mosbesimi, (send) i ndashëm - (send) i pandashëm etc. c) A term may be an antonym with some other terms in various degrees as monogami - bigami - poligami so, in this case the opposition increases and gets more complete from bigami to poligami. The degree of opposition is different between the terms as shtetësi - dyshtetësi -pashtetësi. There are cases when the same term enters in a opposite relation with terms of the same degree as (vendim) $i$ ndërmjetëm - (vendim) përfundimtar - (vendim) jopërfundimtar. In the legal terminology there are also antonymic pairs that are realized in the preset contexts or determined lexical relations when out of them these pairs would not be the same for example (kontribut) në natyrë - (kontribut) në shërbime, (pagim) në natyrë - (pagim) me para, (dëm) material - (dëm) moral, (person) fizik - (person) moral etc.

\section{Conclusions}

The phenomenon of antonymy in terminology has become an important mean of expression of the essential and inevitable phenomena of the science (Samara, 1984, 207). In accordance with this opinion from the analysis of the emergence and development of the phenomenon of antonymy in legal terminology from one period to another is noted that:

From the quantitative side, there are new antonymic pairs added to the teminology. The main place in two periods take the antonymic pairs that name characteristics and the ones that name actions. In the time period after 1990's it should be noted there is a significant increase of the antonymic pairs that name people according to the functions they have or the activities they perform in the relations between them. Antonymic pairs are created on the basis of opposition the words alone or within semantic relations of compound words. The antonymic relations specify the meanings of antonymic terms distinguishing what separates and what unites them in order to determine the best place and use of their special communication.

From the lexical and grammatical affiliation the antonymic pairs are formed by opposition of the terms of the same lexical and gramatical class mainly adjectives, nouns and few verbs, but there are also antonymic pairs that are formed between terms in different lexical and grammar category. New word formations were created on the basis of antonyms of words formed by means of word formation of the existing terms. After 1990's there is an increase of the antonymic nominal pairs formed by the opposition between abstract qualifying nouns and between action nouns.

From the structure, there are antonymic pairs formed through word formation, which constitute the main part of the antonyms in the legal terminology. In this aspect it is noted the increasing role of prefixes for the formation of antonymic 
pairs form adjectives and nouns, but also is seen an increase in the nominal antonymic pairs formed by compound terms with the opposite meaning in the structure of the composition terms.

Antonymy through the prefixes is realized through prefixes with opposite meanings or different prefixes joined to the same base. It should be mentioned that with any prefixes, as in the case of prefix jo-, except the antonymic pairs adjectives that are characteristic for the general language, in the time period after 1990's, the noun antonymic pairs constitute a special feature of the terminological lexicon for example tregtar - jotregtar, kushtetueshmëri jokushtetueshmëri etc.

\section{References}

Delija, Sh. (2010), The lexicon-semantic relations of the antonyms and their composition in the linguistics, Tirane, Geer.

Goçi, I. (1985), The antonyms of the today Albanian language, Prishtine the Albanologic Institute .

Millan Orozoco, A. (1972), "Algunas consideraciones sobre la antonimia", Anuario de letras, 10.

Pasho, H. (1986), An overview on some presentation of the multimeanings od synonymy and antonymy in the terminoly of the economics in Albanian language, SF, 3.

Samara, M. (1985), issues of the antonymy in Albanian language. Tirane.

Thomai, J. (1999) Lexicology of the Albanian language. Tirane. 